Jurnal Indonesia Sosial Teknologi:p-ISSN: 2723 - 6609

e-ISSN :2745-5254

Vol. 3, No.1 Januari 2022

\title{
MEDIA SOSIAL YOUTUBE DAN FACEBOOK DALAM PEMBENTUKAN SIKAP INTELORENSI DAN RADIKALISME CERAMAH USTADZ HASYIM YAHYA "ORANG ISLAM YANG BAIK ITU YANG MENJADI TERORIS"
}

\section{Rikky operiady}

Program Pascasarjana S2 Angkatan 11 STIK PTIK Jakarta

Email: rikkyoperiady73@gmail.com

\begin{abstract}
Abstrak
Era milenial saat ini, modus penyebaran aktivisme berkembang secara masif di dunia daring. Pada tahun 2015, Kementerian Komunikasi dan Informatika (Kemkominfo) memutuskan memblokir 22 website atau situs yang tergolong radikal karena maraknya aktivisme di dunia maya. Pemblokiran situs militan dilakukan di bawah arahan Badan Nasional Penanggulangan Terorisme (BNPT). Distribusi pengguna Internet terutama di Jawa, mencapai $65 \%$, atau 86,3 juta orang. Berdasarkan angka tersebut, 69,9\% atau 92,8 juta orang memakai internet di mana pun mereka ingin. Ini bisa menunjukkan bahwa mereka akan dapat dengan mudah mengakses situs web agresif. Pada saat yang sama, propaganda radikal akan lebih mudah menyebar ke seluruh Indonesia.
\end{abstract}

Kata kunci: Internet, Uses dan Gratification, Terorisme

\section{Abstract}

In the current millennial era, the mode of spreading activism is growing massively in the online world. In 2015, the Ministry of Communication and Information (Kemkominfo) decided to block 22 websites or sites that were classified as radical because of rampant activism in cyberspace. The blocking of militant sites is carried out under the direction of the National Counterterrorism Agency (BNPT). The distribution of Internet users, especially in Java, reached $65 \%$, or 86.3 million people. Based on this figure, $69.9 \%$ or 92.8 million people use the internet wherever they want. This could indicate that they will be able to easily access aggressive websites. At the same time, radical propaganda will more easily spread throughout Indonesia.

Keywords: Internet, Uses and Gratification, Terorisme

\section{Pendahuluan}

Maraknya aksi teror belakangan ini membuat perbincangan tentang aktivisme menjadi topik hangat, dan aktivisme individu sering dihubungkan dengan aksi terorisme karena diklaim sebagai aksi nyata yang bersifat radikal. Namun, mengenai kajian utama majalah "Silat Radikalisme" edisi ke-40 Duia Online, pemerintah Indonesia belum mempunyai istilah yang jelas prihal apa yang dimaksud dengan aktivisme itu sendiri. Pemerintah hanya mengatakan bahwa radikalisme adalah akar dari sebuah gerakan 
Rikky operiady.

teroris, bahwa radikalisme lebih fundamental karena seseorang berpikir secara radikal sebelum melakukan teror atau kekerasan. Sebagaimana KBBI, arti aktivisme diartikan sebagai ajaran atau aliran yang ingin membawa perubahan melalui cara-cara yang tidak baik atau kekerasan. Istilah radikalisme yang tidak jelas juga menjadikan pemerintah kesulitan untuk membasmi gerakan-gerakan yang mengancam kedaulatan nasional Indonesia (Widyaningsih \& Fil, 2019).

Era milenial saat ini, modus penyebaran aktivisme berkembang secara masif di dunia daring. Pada tahun 2015, Kemkominfo memutuskan untuk memblokir 22 link website atau situs yang tergolong radikal karena maraknya aktivisme di dunia maya (Lestari, 2021). Pemblokiran situs militan dilakukan di bawah arahan Badan Nasional Penanggulangan Terorisme (BNPT). Ke-22 situs ini mewakili situs-situs Islam yang aktif menyebarkan aktivisme di dunia maya yang melaluinya mereka dapat mempengaruhi masyarakat. Beberapa dari ke-22 link website tersebut antara lain Eramuslim.com dan Kiblat.net yang sangat kontras, menurut ideologi Majalah Idea edisi ke-40 antara Pancasila dan Islam. Pancasila diklaim sebagai taghut atau idola, produk asing, hingga disetarakan dengan prinsip-prinsip zionis.

Semasa yang sama, Islam dipandang sebagai ideologi negara sampai Khilafah Islam dipaksa untuk menerapkannya di Indonesia (Thoyyib, 2018). Ketika mereka menemukan informasi ini, orang hanya akan percaya kata-kata dan kebenaran yang terkandung dalam situs web. Informasi yang diberikan dibuat dengan hati-hati untuk mengarahkan publik ke tempat yang diinginkan oleh perusahaan media. Selanjutnya, postingan berjudul Apakah Pancasila Layak Berideologi? Pernyataan dari Voaislam.com menyatakan bahwa Pancasila bukanlah ideologi, sehingga tidak layak ditetapkan pedoman hidup seseorang, bangsa dan negara, serta tidak mempunyai prasarana yang jelas. Selama Indonesia masih menganut Pancasila sebagai ideologinya, tidak akan pernah berkembang. Begitulah cara mereka melakukan propaganda untuk menghilangkan minat mereka pada aktivisme yang dipaksakan.

Media radikal menggunakan berbagai cara guna menggugurkan semua orang yang diklaim kontradiktif. Isu SARA, ujaran kebencian, dan hoax yang mereka ciptakan tanpa memperhatikan etika jurnalistik. Semisal, kabar berjudul "Pakar Hukum: Ahok Harus Ditangkap Sekarang" di upload oleh Eramuslim.com. dalam berita tersebut, unsur $5 \mathrm{~W}+1 \mathrm{H}$ belum sepenuhnya terwujud, juga tidak disebutkan kapan, di mana, dan di forum mana sumber berita berdialog dengan media. Pemberitaan itu juga hanya mengomentari ahli hukum sebagai narasumber, yakni Martimus Amin. Dikatakan jika Ahok masih dibiarkan bebas akan membahayakan keamanan negara.

Sejalan dengan penyebaran aktivisme yang meluas, Badan Intelijen Nasional (BIN) menerbitkan temuannya di tahun 2017. 39\% siswa di negara Indonesia sudah tercemar radikalisme, dan $24 \%$ siswa dan 23,3\% siswa SMA setuju untuk mendirikan negara Islam di Indonesia. Demikian diutarakan Kepala BIN Budi Gunawan saat memberikan sambutan di BEM PTUN di Unwahas, Semarang, Indonesia. Data yang 
Media Sosial Youtube dan Facebook dalam Pembentukan Sikap Intelorensi dan Radikalisme Ceramah Ustadz Hasyim Yahya "Orang Islam yang Baik itu yang Menjadi Teroris"

cukup guna memperlihatkan bagaimana proses aktivisme menyebar di area pendidikan.7

Pancasila dan Bhinneka Tunggal Ika juga semakin dipersoalkan seiring maraknya penyebaran radikalisme yang berujung pada khilafah dan intoleransi terhadap terorisme. Semasa tahun 2016, Wahid Foundation bermitra dengan Lembaga Penyelidikan Indonesia (LSI) melakukan survei nasional bertajuk "Potensi Intoleransi dan Radikalisme dalam Umat Beragama Muslim di Indonesia”. Mengenai survei tersebut, timbul beberapa data yang agak meragukan. Berdasarkan sejumlah 1.520 responden, 59,9\% termasuk kelompok pembenci, kelompok Tionghoa, komunis, dan lain sebagainya dengan latar belakang agama non-Muslim. 8

Selain itu, berbagai jaringan teroris menggunakan bom di Indonesia, antara lain bom 2000 gereja di Kota Batam, Kota Pekanbaru, Kota Jakarta, Kota Mojokerto, Kota Kudus dan Kota Mataram, Paddy's Pub dan Sari Club (SC). 2002 di Bali, 2003 JW Marriott Hotel I, 2004 Kantor Kedutaan Besar Australia, 2009 JW Marriott Hotel II dan The Ritz-Carlton Jakarta, Polsek Cirebon 2011, Polres Cirebon 2013, Polres Poso 2013, J1 . MH Thamrin tahun 2016, dan 2017 di Terminal Trans Jakarta Kampung Melayu.9 Aksi nyata bermula dari pemahaman aktivisme dalam berbagai studi populasi.

Sejak kemunculan ISIS pada tahun 2013, pola radikalisasi terus berkembang sehingga berdampak besar bagi masyarakat. Negara Islam Irak dan Suriah atau ISIS sudah menjadi berita di berbagai media dalam negeri dan luar negeri karena mereka melakukan teror, kekejaman dan penghancuran atas nama Islam. Proses rekrutmen telah bergeser dari rekrutmen menjadi harus bertatap muka dan kini dapat dilaksanakan melalui media sosial. Mereka menjual YouTube alternatif, kehidupan sejahtera yang ditawarkan di bawah paying lindung Khilafah Islamiyah melalui kesaksian beberapa yang telah sukses didoktrin di media sosial ( $\underline{\mathrm{Ar}}, 2013)$.

Janji-janji ISIS juga berhasil meyakinkan kelompok-kelompok, tidak hanya dari kelas bawah, tetapi 50 persen dari mereka yang terpengaruh hingga ke jenjang perguruan tinggi. Demikian itu dipaparkan Kepala BNPT Komjen Suhardi Alius pada waktu diwawancarai 75 WNI yang dideportasi dari Turki karena diperkirakan bergabung dengan ISIS di Cipayung, Jakarta Timur. Senin (17/6/17). ${ }^{12}$ Mengenai hubungannya dengan aktivisme, agama sebenarnya bisa mewadahi berbagai masalah mendasar atau sangat fundamental yang dikandungnya. Hal itu dipastikan bahwa pendekatan yang digunakan para ahli selalu dipengaruhi oleh latar belakang intelektual yang mereka libatkan, termasuk para pakar yang hanya mengkhususkan pada bidang agama tertentu.

Agama dalam arti non-chaotic sebenarnya disalahgunakan guna menimbulkan teror, melegitimasi pembunuhan dan kejahatan guna tujuan politik. Arti tidak bingung dapat diartikan sebagai pernyataan bahwa peraturan yang berlaku dalam suatu agama memberikan hasil moral dan materi dari pemeluknya, yang dianggap oleh khalayak umum yang berpengetahuan. Fenomena kehidupan beragama di masyarakat pada lumrahnya merupakan deskripsi dari agama penduduk. Agama dimaknai sebagai didikan yang harus dan benar serta tidak bisa dipersalahkan karena bermula dari Tuhan. 
Rikky operiady.

Sementara itu, agama didefinisikan sebagai sikap atau perilaku masyarakat untuk menerapkan agama itu sendiri (Syakirin, Aziz, \& Surayya, 2020).

Tingkah laku dan pengetahuan radikal mengenai agama masuk dalam ruang lingkup perilaku masyarakat ketika menerapkan agama sesuai pemahamannya (Usman, Qodir, \& Hasse, 2014). Berbagai isu juga mudah tersebar, karena sebagaimana Survei Perilaku dan Penetrasi Pengguna Internet Indonesia 2016, APJII mengatakan bahwa populasi pemakai Internet Indonesia adalah 132,7 juta orang, menyumbang 51,8\% dari keseluruhan penduduk atau sejumlah 256,2 juta orang. Sebaran pemakai internet terutama di pulau Jawa mencapai $65 \%$ atau 86,3 juta user. Menurut angka tersebut, $69,9 \%$ atau 92,8 juta orang memakai internet di mana pun. Ini mungkin menunjukkan bahwa mereka akan dapat dengan mudah mengakses situs web agresif. Pada saat yang sama, propaganda radikal akan lebih mudah menyebar ke seluruh Indonesia.

Permasalahan tersebut di atas menunjukkan bahwa anti radikalisme diperlukan untuk mengatasi dan memerangi ide-ide radikal yang menyebar di dunia nyata dan dunia maya. Mengingat semakin pesatnya penyebaran informasi di bidang siber, maka anti radikalisme di dunia maya perlu mendapat perhatian lebih. Antiradikalisme dapat muncul dalam bentuk artikel, berita, visual, dan teknologi penyebaran informasi yang bisa diakses oleh semua orang. Melalui hal tersebut, penelitian ini berupaya untuk mengeksplorasi bagaimana portal online dapat melawan radikalisme. Gerbang daring yang dipilih merupakan dari kalangan ormas Islam dan anggota pemerintah. Ormas Islam Nahdlatul Ulama (NU) dan Muhammadiyah menjadi sampel penelitian ini karena merupakan ormas utama yang digunakan oleh umat Islam di Indonesia. NU, yang memiliki dasar massa dari 40 juta orang lebih, akan dianggap penting di antara mereka.

Sementara itu, Muhammadiyah adalah kelompok Islam besar lainnya, dengan sekitar 14 persen dari populasi Muslim Indonesia berpartisipasi. ${ }^{16}$ Kedua kelompok ini berperan penting dalam berbagai hal, dan diharapkan mampu melawan aktivisme di dunia daring. Situs portal online NU terdapat Nu.or.id dan Dutaislam.com yang dipelihara secara individu oleh personel NU dan pendukungnya. Dutaislam.com bisa dianggap sangat tidak lunak dan agresif kontra-narasi, termasuk aktivisme, ujaran kebencian dan hoax. Gerbang tentu memiliki pola yang tidak sama dalam hal kontraaktivisme, yang akan peneliti bahas dalam penelitian ini.

Adapun di Muhammadiyah terdapat gerbang Suaramuhammadiyah.id adalah website legal Majalah Suara Muhammadiyah Pimpinan Pusat Muhammadiyah. Sedari dulu (1915), Suaramuhammadiyah.id muncul dalam bentuk surat kabar Majalah Suara Muhammadiyah. Kini, majalah tersebut muncul dalam edisi digital dan cetak dan dipelihara langsung oleh perwira-perwira muda Mohammad. Disponsori oleh PT Syarikat Cahaya Media, moto situs ini adalah "Menyemangati dan Menginspirasi". ${ }^{17}$ Adapun Sangpencerah.id yang dipelihara sendiri oleh kaum muda Muhammadiyah. Pemerintah sendiri, mereka juga aktif melawan ide-ide radikal. BNPT sebagai lembaga pemerintah yang diberdayakan guna menangani terorisme mempunyai lembaga khusus guna menangani radikalisme di dunia daring, yaitu Peaceful Media Center (PMD). 
PMD secara aktif menghasilkan konten positif untuk memerangi aktivisme yang berkembang. Melalui PMD ini, timbul berbagai portal online yang aktif dalam penelitian kontra radikalisme, termasuk Jalandamai.org. Situs ini dirancang untuk berbagi pengetahuan, menumbuhkan dan mendoktrin pikiran keramahan dan toleransi. Situs ini dimulai oleh sekelompok intelektual muda yang berkomitmen kuat untuk menjadi duta perdamaian Indonesia. Kajian ini akan mengkaji secara lebih spesifik peran model portal online dalam kontra aktivisme, melalui konten yang mereka hasilkan, baik berupa artikel, berita, grafik, baik dari intensitasnya.

\section{Metode Penelitian}

Penelitian ini merupakan penelitian kepustakaan. Penelitian kepustakaan adalah studi pengumpulan informasi dan data dengan bantuan bermacam bahan di perpustakaan ( Sari \& Asmendri, 2020). Penelitian kepustakaan juga bisa menelaah bermacam buku referensi dan temuan penelitian sejenis terdahulu, yang bermanfaat guna memperoleh teori fundamental bagi pertanyaan penelitian (Anshori \& Iswati, 2019). Penelitian kepustakaan juga mengandung pengertian cara pengumpulan data dengan berkonsultasi dengan buku, literatur, catatan, dan berbagai laporan yang berkaitan dengan persoalan yang akan diselesaikan (Hermawan, 2019). Adapun sebagaimana para pakar lain, studi literatur adalah kajian teori, referensi, dan tulisan ilmiah lainnya terkait budaya, nilai, dan norma yang dikembangkan dalam konteks sosial yang diteliti (Sugiyono, 2014).

Metode penelitian kepustakaan ini dipakai guna mengembangkan rancangan tentang expressive writing (EW) agar bisa dijadikan dasar untuk mengembangkan langkah-langkah praktis sebagai alternatif konsultasi. langkah-langkah penelitian kepustakaan merupakan berikut ini : 1. Memilih kajian 2. Menggali data 3. Mengidentifikasi prioritas kajian 4. Mengumpulkan sumber data 5. Menyiapkan penyajian data 6. Menyiapkan laporan Sumber data menjadi sumber data bahan kajian ini akan berupa buku, jurnal dan situs internet yang berhubungan dengan topik yang dipilih. Sumber data untuk penelitian ini meliputi 5 buku dan 14 jurnal tentang konsultasi Expressive Writing (EW).

Teknik pengumpulan data mengenai penelitian ini merupakan berasal dari berkas, diantaranya mencari informasia tentang hal-hal atau variabel yang berupa catatan, buku, makalah atau karya tulis, jurnal, dan lain-lain (Penyusun, 2013). Alat penelitian dalam penelitian ini merupakan daftar pengelompokkan bahan penelitian, pola tulisan atau peta, dan format catatan penelitian. Teknologi analisis data yang digunakan dalam penelitian ini merupakan analisis isi. Analisis ini dipakai untuk memperoleh inferensi yang valid dan bisa diuji kembali sesuai konteksnya.

\section{Hasil dan Pembahasan}

Secara etimologis, agama berawal dari bahasa Sansekerta, yang terdiri dari A untuk perselisihan dan GAMA untuk kebingungan. Mengenai bentuk harafiahnya yang terpadu, kata religi berarti "jangan tinggalkan, tetap di tempat, tabah, hamba turun- 
Rikky operiady.

temurun". Sebagaimana dalam KBBI, agama diartikan sebagai didikan atau peraturan yang memerintah tentang keyakinan dan sistem peribadatan kepada Tuhan Yang Maha Esa, serta aturan-aturan yang berkaitan dengan sesama manusia dan sekitarnya.

Orang Barat menyamakan agama dengan religere. Kata religere berawal dari bahasa latin dan terdiri dari dua bagian yaitu "re" yang berarti kembali dan "ligere" yang artinya berhubungan atau terikat, karena perlu hukum untuk mengikatnya. Kata ad-din memiliki banyak arti harfiah, yaitu pahala, persediaan, kekuasaan, pengaturan, dan kalkulasi. Ulama Islam mengistilahkan agama sebagai hukum pedoman manusia dari Tuhannya, dan menarik mereka untuk masa kini dan masa depan, perjuangan untuk hidup.

Sebagaimana penjelasan di atas, agama yang sebenarnya digunakan sebagai alat untuk mengatur kehidupan dan pekerjaan masyarakat secara damai dan tenteram, telah berubah menjadi sarana saling tuding, perusakan dan kejahatan. Agama seolah menjadi didikan yang harus diterapkan dan dipercayai sepenuh hati, namun bisa dikatakan pemahaman yang salah akan mampu mengubah esensi agama yang dibuat sebagai sistem tatanan kehidupan. Titik tolaknya adalah wahyu atau penafsiran tentang bagaimana Tuhan menyampaikan doktrin-doktrin agama, di mana doktrin-doktrin itu mulai dimengerti dan disebarkan.

Berkenaan dengan radikalisme agama, Akbar S. Ahmed berpendapat bahwa radikalisme sama dengan fundamentalisme Islam, yang terutama ditandai dengan vulgar dan kecenderungan untuk menggunakan bahasa yang kasar dan kotor untuk menganiaya lawan politik, bahkan jika mereka tidak menyadarinya. diklaim dan diperjuangkan, dengan cara yang brutal. Radikalisme agama kerap diucap dengan al-tațharuf al-diny yang artinya berdiri di ujung, atau menjauhi tengah, atau bisa juga didefinisikan melakukan sesuatu yang berlebihan. Pada awalnya, al-ta'haruf didefinisikan sebagai sesuatu yang konkrit. Namun, penjelasan berikut adalah hal-hal yang abstrak, seperti overthinking, melakukan sesuatu, dan keyakinan agama. Menurut Syafi'i Anwar, ada dua alasan munculnya kelompok radikal. Pertama, umat Islam yang kecewa dan terasing karena "tertinggalnya" kemajuan peradaban Barat dan akomodasi yang berlebihan terhadap berbagai budaya. Karena mereka tidak bisa mengikuti perkembangan budaya Barat, untuk menghadapinya mereka menggunakan kekerasan. Kedua, munculnya kelompok radikal karena kedangkalan agama.

Situasi ini terjadi karena mereka yang pernah terdoktrin atau berpartisipasi dalam gerakan Islam radikal atau garis keras biasanya terdiri dari orang-orang dengan latar belakang pendidikan non-agama. Mereka hanya memahami agama berdasarkan pemahaman kata atau nash. Pemahaman substantif mereka kepada pemahaman Islam bisa disebut tidak kuat, karena mereka belum memahami berbagai tafsir, kaidah ushul fiqh, dan perubahan pengertian nash yang ada. Ketika membaca ayat-ayat Al-Qur'an, mereka melakukannya dalam "kesepian", sehingga konsep moral dan latar belakang sejarah tidak ada hubungannya dengan interpretasi mereka. Padahal, sangat penting 
Media Sosial Youtube dan Facebook dalam Pembentukan Sikap Intelorensi dan Radikalisme Ceramah Ustadz Hasyim Yahya "Orang Islam yang Baik itu yang Menjadi

Teroris"

untuk memahami latar belakang turunnya ayat-ayat Al-Qur'an, karena Al-Qur'an tidak lahir begitu saja.

Berbagai ciri yang dapat diidentifikasi dari tindakan dan pemahaman radikal tersebut adalah: intoleransi (enggan menghormati pendapat dan kepercayaab orang lain), fanatisme (kerap berprasangka benar dan menjustifikasi orang lain salah), eksklusivitas (memanfaatkan diri sendiri dan kaum Islam pada biasanya), revolusioner. ${ }^{5}$ Horace M. Callen berpendapat bahwa aktivisme disertai dengan tiga karakteristik. Pertama, aktivisme merupakan respon terhadap situasi saat ini dalam wujud evaluasi, penolakan, atau perlawanan. Kedua, aktivisme tidak berhenti berusaha menolaknya, tetapi terus berusaha merubah aturan yang berlaku dengan wujud aturan nilai yang lain.

Ketiga, kaum radikal yakin akan otentisitas program atau ideologi yang diusungnya. Sebelum seseorang atau kelompok menggunakan aktivisme, ada proses radikalisasi. Mereka sudah berproses transformasi yang mengakibatkan penolakan untuk menggunakan kekerasan untuk mencapai nilai dan institusi mereka. Proses radikalisasi Cilluffi dan Saathof meliputi 2 jenis: radikalisasi individu dan radikalisasi kelompok. Radikalisasi pribadi diakibatkan oleh keterpaparan individu terhadap sumber online atau pihak lain dengan pemikiran yang ekstrim, yang dikenal dengan istilah lone wolf atau serigala penyendiri yang menjalani proses radikalisasi sendirian. Perseorangan tidak harus terkoneksi ke jaringan teroris, tetapi dengan mudah direkrut ke dalam jaringan teroris. Selain itu, radikalisasi kelompok adalah proses dimana sekelompok mencari dan mendoktrin perseorangan yang mudah guna direkrut ke dalam koneksi teroris, dengan memakai program rekrutmen top-down yang terstruktur.

Aktivisme menyebar luas melalui sarana agama, dan bermacam kelompok dalam daftar radikal hanya dapat menghasut berbagai kelompok untuk berpartisipasi dalam aktivisme mereka dengan menambahkan bumbu pada ayat-ayat model mereka. Pergerakan grup radikal atas nama agama termasuk dalam gerakan Islam alternatif. Grup itu percaya bahwa kelompok Islam arus utama seperti NU dan Muhammadiyah tidak dapat mewujudkan "Islam yang benar" dan mengatasi berbagai ketidakadilan di masyarakat.

Secara umum, ada dua mode gerakan untuk gerakan Islam non-mainstream. Pertama, gerakan non-Salafi dipadukan dengan antusias literal ajaran Kafa. Beberapa kelompok tersebut antara lain Darul Arqam, Jamaah Tabligh, Ihwanul Muslim, Isa Bugis, IJABI, FPI, DI, HTI, dan lain sebagainya. Kedua, gerakan Salafi berupaya mencapai harapan sosial-politik Islam yang tidak sama dengan yang diungkapkan oleh gerakan-gerakan Islam arus utama.

Kelompok yang termasuk adalah MMI, Laskar Jihad, Jamaah Islamiyah. Keduanya berkembang sekaligus bersinggungan dengan semua pihak, dan gerakan alternatif tersebut dapat dibagi menjadi tiga bagian, yaitu jihadis, reformis, dan rejeksionis. Para jihadis melakukan pergerakan politik berupa aksi kekerasan yang mengatasnamakan jihad, dan para pelakunya bersedia mengorbankan nyawanya demi janji surga. Pada saat yang sama, kaum reformis mengambil tindakan politik dalam bentuk tekanan kepada pemerintah, dari pada menggunakan kekerasan yang dapat 
Rikky operiady.

menggoyahkan negara dan mengklaim hak sektarian. Kita dapat melihat bahwa dalam beberapa tahun terakhir telah terjadi proliferasi multi-volume pembelaan agama. Rejektionis merupakan bentuk aksi politik yang menolak demokrasi dan memberikan dorongan pada bermacam konsep.

Hammami Zada mencatat ada 2 tren gerakan yang muncul, yakni gerakan yang lebih formal (berorientasi politik) dan gerakan kultural-religius (berorientasi budaya). Gerakan religiusme yang bertujuan politik disimbolkan dengan timbulnya bermacam partai politik berdasar Islam. Gerakan politik Islamis lebih ditujukan pada berbagai tujuan politik, ada yang hanya berusaha mendapatkan dukungan dari umat Islam dan ada juga yang lebih ditekan oleh ideologi. Aspirasi ideologis yang dituju adalah mereka meyakini bahwa kaidah-kaidah Islam harus dibela melalui lembaga formal dan dilegitimasi oleh hukum. Lebih jauh lagi, Gerakan Islam Budaya adalah gerakan Islam garis keras yang diproklamirkan secara terbuka.

Berbagai kelompok gerakan tersebut antara lain Front Pembela Islam yang didirikan oleh Rizieq Shihab di Jakarta pada 17 Agustus 1998, Laskar Ahlul Front Komunikasi Sunnah wa Al-Jama'ah Thalib yang dikomandoi oleh Ja'far Ummar Didirikan di Thoreau pada 12 Februari 1998. Majelis Mujahidin Indonesia kemudian dibentuk di Solo yang dikaderi oleh Abu Bakar Basyir. Gerakan-gerakan ini berusaha untuk menciptakan "negara Islam" atau setidaknya menerapkan hukum Islam. Gerakangerakan ini percaya bahwa masalah negara Indonesia hanya bisa diakhiri melalui penerapan hukum Syariah.

Mereka menggunakan metode yang berbeda untuk mempertahankan ide-ide yang mereka percayai. Cara damai digunakan oleh HTI, Jamaah Tarbiyah atau Harokah Ikhwanul Muslimin. Pada saat yang sama, kekerasan dimulai dengan perusakan atau kekejaman, dengan menyerbu tempat-tempat yang dianggap tidak bermoral, Sama seperti FPI. Ada lagi bentuk kekerasan yang lebih ekstrim yaitu melakukan aksi terorisme, yakni pengeboman atau penembakan, seperti yang dilakukan Jemaah Islamiyah (JI) dalam bom Bali 1 yang menewaskan ratusan korban. Mereka semua memiliki cita-cita yang sama, yaitu mendirikan kekhalifahan Islam.

Selain itu, karena penyebaran informasi yang cepat, internet tidak sekedar memberikan efek positif bagi pemakainya, tetapi juga bermacam efek negatif. Beberapa di antaranya untuk menyebarkan radikalisme ke terorisme. Dalam dunia terorisme, kelompok militan melakukan berbagai aktivitas untuk mempengaruhi semua pihak. Mereka menggunakan 9P, yaitu propaganda, rekrutmen, pelatihan, logistik, pembentukan pasukan paramiliter ilegal, perencanaan, pelaksanaan serangan teroris, penyembunyian dan pembiayaan. Kegiatan ini dilakukan untuk menginformasikan dan membiasakan masyarakat dengan ideologi mereka.

Propaganda aktivisme yang tersebar di internet dikemas sedemikian rupa dan disebarkan melalui berbagai website atau media sosial. Mereka menggunakan layanan gratis untuk membuat blog dengan menggunakan domain yang tampak seperti situs Islami yang tidak menyimpang. Termasuk materi tentang aktivisme yang menggunakan 
teks-teks keagamaan untuk menyentuh hati guna mempengaruhi pembaca. Internet menawarkan banyak kesempatan bagi kelompok aktivis untuk melakukan berbagai aksi. Peluang tersebut antara lain:

1. Ciptakan kesempatan untuk mengekspos seseorang pada ideologi radikal. Secara tidak langsung, Internet memfasilitasi penyebaran aktivisme melalui situs-situs radikal dengan jangkauan yang sangat luas.

2. Internet telah menjadi ruang gema bagi ideologi radikal. Internet telah memudahkan pengguna untuk memperoleh materi yang menarik, termasuk propaganda teroris, melalui situs web tertentu, blog, jejaring sosial, formulir Internet, fasilitas obrolan, dan aliran video.

3. Internet telah mempercepat radikalisasi. Dalam konteks ini, Internet telah memudahkan untuk memperoleh informasi dan mempromosikan aktivisme.

4. Internet menawarkan peluang untuk radikalisasi tanpa kontak fisik.

5. Internet meningkatkan peluang radikalisasi diri. Pengguna internet dapat mempelajari lebih lanjut tentang pola aktivitas teroris tanpa harus bersentuhan langsung dengan teroris lain. Ini karena pengguna Internet memiliki akses ke banyak informasi dan memahami pola aktivitas teroris di Internet.

\section{Pengertian Kontra Radikalisme}

Dalam KKBI, kata "con" diartikan sebagai tidak setuju, tidak setuju, dan lain sebagainya.12 Kontra-radikalisme adalah upaya untuk menanamkan nilai-nilai Indonesia serta nilai-nilai non-kekerasan. Strategi ini dilaksanakan melalui pendidikan formal dan nonformal. Deradikalisasi ini dilakukan melalui tokoh agama, tokoh agama, Pendidikan, tokoh masyarakat, tokoh adat, tokoh pemuda dan pemangku kepentingan lainnya memberikan nilai-nilai kebangsaan untuk memerangi radikalisme. Antiradikalisasi adalah bagian dari deradikalisasi untuk anti-radikalisasi. Deradikalisasi ini untuk simpatisan, Pendukung, inti dan militan dilakukan di dalam dan di luar penjara. Tujuannya adalah agar kelompok inti, simpatisan radikal, dan pendukung meninggalkan cara-cara kekerasan dan teror dan memoderasi mereka saat mereka memperjuangkan misi mereka. Ide-ide radikal mereka menjadikan mereka sesuai dengan etos kelompok Islam moderat dan sesuai dengan misi nasional yang memperkuat bangsa dan bangsa.

Deradikalisasi memiliki tiga dimensi, yaitu sebagai strategi, program dan sistem kelembagaan. Antiradikalisasi mencakup upaya khusus dari deradikalisasi sebagai dimensi strategis. Ini ditujukan untuk masyarakat umum, apakah mereka telah terkena aktivisme atau tidak. Harapan peningkatan imunitas dan stamina bagi yang belum terpapar kesadaran ini dengan cara ini orang kurang rentan terhadap persuasi tradisional dan media sosial. Sasaran utama dari kontra aktivisme ini adalah generasi muda yang sedang menempuh pendidikan di bangku sekolah menengah hingga perguruan tinggi. Tugas dan tanggung jawab pemberantasan radikalisme dan terorisme tidak hanya menjadi tanggung jawab pemerintah, tetapi juga tanggung jawab seluruh lapisan masyarakat. Saat ini, partisipasi masyarakat masih sangat dibutuhkan untuk mengisi dunia maya dengan konten-konten positif atau anti radikal. 
Rikky operiady.

Dalam memerangi propaganda radikalisme dan terorisme melalui media internet, diperlukan peran berbagai kalangan, baik itu urama, tokoh pendidikan, tokoh agama, tokoh pemuda, tokoh masyarakat, dll. Dalam kontra radikalisme, ada 20 indikator yang bisa dijadikan parameter untuk mengukur kecenderungan ekstremisme agama, yaitu:

a. Gerakan memiliki kecenderungan untuk menyimpang dari arus utama atau menolak tatanan dunia, politik dan sosial;

b. Upaya untuk menggulingkan tatanan politik untuk menciptakan kembali apa yang mereka anggap sebagai tatanan alam masyarakat, yang dapat Berdasarkan ras, kelas, kepercayaan dan keunggulan ras;

c. Memiliki ideologi dan rencana aksi yang bertujuan untuk memperoleh kekuatan politik atau komunitas;

d. Menolak atau mengaburkan gagasan ketertiban hukum dalam masyarakat demokratis; menggunakan ruang politik yang disediakan oleh lembagalembaga demokrasi untuk memajukan tujuan mereka merebut kekuasaan;

e. Menolak Deklarasi Internasional Hak Asasi Manusia, menunjukkan ketidakmampuannya dan tidak mengakui hak orang lain;

f. Menolak prinsip demokrasi berdasarkan kedaulatan rakyat;

g. Penyangkalan umum terhadap kesetaraan, terutama bagi perempuan dan minoritas;

h. Menolak keragaman dan pluralisme, bahkan menganjurkan sistem monokultural (masyarakat monokultural);

\section{Theory Uses dan Gratification}

Apa yang disebut oleh para sarjana komunikasi massa saat ini sebagai Uses dan Gratification? (U\&G) pendekatan umumnya diakui sebagai subtradisi penelitian efek media. Berdasarkan awal mula sejarah penelitian komunikasi, sebuah pendekatan dikembangkan guna mempelajari kepuasan yang menarik dan menahan audiens untuk jenis media dan jenis konten yang memenuhi kebutuhan sosial dan psikologis mereka (Hadi, 2021). Banyak penelitian efek awal mengadopsi eksperimen atau pendekatan kuasi-eksperimental, di mana keadaan komunikasi dimanipulasi untuk mencari pelajaran umum tentang bagaimana berkomunikasi yang lebih baik, atau tentang konsekuensi pesan yang tidak diinginkan (Manab, 2015).

Penelitian efek media lainnya berusaha menemukan motif dan pola seleksi khalayak untuk media massa depan. Contohnya termasuk Cantril dan Allport (1935) pada penonton radio; Waples, Berelson, dan Bradshaw (1940) tentang membaca; Herzog $(1940,1944)$ mengenai program kuis dan gratifikasi dari serial radio siang hari; Suchman (1942) mengenai motif mendengarkan musik yang serius; Wolfe dan Fiske (1949) mengenai minat anak terhadap komik; Berelson (1949) mengenai fungsi membaca koran; dan Lazarsfeld dan Stanton $(1942,1944,1949)$ di media yang berbeda genre. Masing-masing studi ini merumuskan daftar fungsi yang dilayani oleh beberapa konten tertentu atau oleh media itu sendiri: 
Media Sosial Youtube dan Facebook dalam Pembentukan Sikap Intelorensi dan Radikalisme Ceramah Ustadz Hasyim Yahya "Orang Islam yang Baik itu yang Menjadi

Teroris"

Guna mencocokkan akal dengan yang lain, untuk mendapatkan informasi dan saran untuk hidup keseharian, guna menyediakan konsep kerja untuk hari seseorang, guna mempersiapkan diri secara budaya untuk tuntutanmobilitas ke atas, atau untuk diyakinkan tentang martabat dan kegunaan peran seseorang. (Blumler \& Katz, 1974).

Penelitian terakhir berfokus pada psikologi sosial dan pendekatan berbasis audiens, diwujudkan sebagai pendekatan U\&G (McQuail, 1994) Beberapa pakar komunikasi massa mengutip "kepanikan moral" dan penelitian Dana Payne sebagai nenek moyang teori U\&G. Studi Dana Payne oleh American Film Research Council dilakukan pada akhir 1920-an. Sosiolog dan psikolog terkemuka, termasuk Herbert Blumer, Philip Hauser, dan LL Thurstone, berusaha mengerti bagaimana menonton film memengaruhi kelompok muda di Amerika Serikat (Lowery \& De Fleur, 1983).

Namun, Rosengren, Johnson-Smaragdi, dan Sonesson (1994) berpendapat bahwa, Studi Dana Payne adalah studi advokasi yang digerakkan oleh efek, yang bertentangan dengan tradisi U\&G yang berfokus pada penggunaan media pribadi. Demikian pula, studi Cantril tentang siaran radio Orson Welles "Perang Dunia" lebih fokus pada faktor sosiologis dan psikologis yang terkait dengan perilaku panik daripada mengembangkan teori efek komunikasi massa (Lowery \& De Fleur, 1983). Dominick mengusulkan bahwa U\&G dimulai pada tahun 1940-an, disaat para peneliti menjadi tertarik mengapa khalayak terlibat dalam bermacam bentuk media perilaku, semisal mendengarkan radio atau membaca surat kabar. Penghargaan lebih lanjut diberikan pada pandangan $U \& G$, penghargaan langsung dan model penghargaan tertunda dari kepuasan media.

Bagaimanapun, penelitian U\&G awal sebagian besar deskriptif, mencoba mengklasifikasikan reaksi anggota audiens ke dalam kategori yang bermakna (Merton, 1949). Kebanyakan sarjana setuju bahwa ada sedikit koherensi teoretis dalam penelitian sebelumnya, sebagian besar kecenderungan metodologis terhadap behaviorisme dan individualisme (McQuail, 1994). Para peneliti berbagi pendekatan kualitatif dengan mencoba mengelompokkan fakta kepuasan ke dalam kategori berlabel, sebagian besar tidak acuh terhadap distribusi frekuensi mereka mengenai populasi. Sebagian besar penulis awal tidak mencoba untuk menelusuri hubungan antara kepuasan terukur dan asal-usul psikologis atau sosiologis dari kebutuhan yang memuaskan. Mereka sering gagal menemukan secara kuantitatif dan konseptual hubungan timbal balik antara berbagai fungsi media yang mungkin mengarah pada penemuan struktur yang mendasari kepuasan media.

Kritik mengenai penelitian U\&G sebelumnya telah berfokus pada fakta bahwa (a) sangat bergantung pada laporan diri, (b) belum dewasa tentang asal usul sosial tuntutan audiens dari media, dan (c) terlalu tidak kritis terhadap kedua kemungkinan disfungsi . Jenis kepuasan penonton tertentu, dan (d) ketertarikan berlebihan pada penonton kreatif yang terbiasa berfokus pada kendala tekstual (Blumler \& Katz, 1974).

Terlepas dari keterbatasan yang serius, para peneliti awal, terutama di Biro Penelitian Sosial Terapan Universitas Columbia, bertahan, terutama dalam mempelajari efek media massa pada sikap politik. Mereka mempelajari pemilih di Erie County, 
Rikky operiady.

Ohio, selama pemilihan Roosevelt dan Wilkie 1940 (Hynek, 2017) dan pemilih di Elmira, New York, selama demokrasi Truman-Dewey 1948. Kedua studi menunjukkan bahwa media massa memainkan peran yang lebih lemah dalam pengambilan ketentuan pemilu dikomparasikan dengan pengaruh pribadi dan pengaruh orang lain. Oleh karena itu, Berelson et al. Mulailah memperkuat riset aliran dua langkah, menjauh dari konsep audiens "atomik" dan menuju pengaruh pengaruh pribadi (Blumler \& Katz, 1974).

Riset ketergantungan media sendiri berasumsi bahwa pengaruh media diputuskan oleh hubungan antara media, khalayak dan masyarakat (Loges \& BallRokeach, 1993). Keinginan individu terhadap informasi media merupakan variabel pertama yang menjabarkan mengapa informasi media mempunyai efek kognitif, afektif, atau variabel. Ketergantungan media tinggi ketika kepuasan tujuan individu bergantung pada pembentukan sistem media (Loges \& Ball-Rokeach, 1993). Rubin dan Windahl memperluas model ketergantungan untuk memasukkan kepuasan pencarian penonton sebagai komponen interaktif dengan ketergantungan media. Bagi Rubin dan Windahl, kombinasi dari kepuasan yang diterima dengan baik dan ketergantungan yang ditentukan secara sosial menciptakan efek media. Mereka berpendapat bahwa ketergantungan pada nama media atau informasi muncul ketika individu dengan sengaja mencari informasi atau terbiasa menggunakan saluran komunikasi atau informasi tertentu.

Misalnya, (Mcllwraith, 1998) menemukan bahwa orang-orang yang menyebut diri mereka "Facebook dan Youtuber" sering menggunakan televisi untuk mengalihkan diri dari pikiran yang tidak menyenangkan, mengatur emosi, dan menghabiskan waktu. Hubungan antara ketergantungan dan alternatif fungsional ini menggambarkan bagaimana U\&G dapat menjadi teori 'mampu menghubungkan komunikasi individu dan termediasi'.

\section{Kesimpulan}

Era milenial saat ini, modus penyebaran aktivisme berkembang secara masif di dunia online. Pada tahun 2015, Kementerian Komunikasi dan Informatika (Kemkominfo) akhirnya memblokir 22 website/website yang tergolong radikal karena maraknya aktivisme di dunia maya. Pemblokiran situs militan dilakukan di bawah arahan Badan Nasional Penanggulangan Terorisme (BNPT). Distribusi pengguna Internet terutama di Jawa, mencapai 65\%, atau 86,3 juta orang. Menurut data, 69,9\% atau 92,8 juta user menggunakan internet di mana saja. Ini menunjukkan bahwa mereka akan dapat dengan mudah mengakses situs web agresif. Pada saat yang sama, propaganda radikal akan lebih mudah menyebar ke seluruh Indonesia. 
Media Sosial Youtube dan Facebook dalam Pembentukan Sikap Intelorensi dan Radikalisme Ceramah Ustadz Hasyim Yahya "Orang Islam yang Baik itu yang Menjadi Teroris"

\section{Bibliografi}

Anshori, Muslich, \& Iswati, Sri. (2019). Metodologi penelitian kuantitatif: edisi 1. Airlangga University Press.

Ar, Eka Hendry. (2013). Pola Gerakan Islam Garis Keras di Indonesia. Jurnal Khatulistiwa LP2M IAIN Pontianak, 3(2), 163-174.

Blumler, Jay G., \& Katz, Elihu. (1974). The Uses of Mass Communications: Current Perspectives on Gratifications Research. Sage Annual Reviews of Communication Research Volume III.

Hadi, Ido Prijana. (2021). Penelitian Media Kualitatif-Rajawali Pers. PT. RajaGrafindo Persada.

Hermawan, Iwan. (2019). Metodologi Penelitian Pendidikan (Kualitatif, Kuantitatif dan Mixed Method). Hidayatul Quran.

Hynek, Jeřábek. (2017). Paul Lazarsfeld and the origins of communications research. Routledge.

Lestari, Ambar Sri. (2021). Narasi dan Literasi Media dalam Pemahaman Gerakan Radikalisme: Konsep dan Analisis-Rajawali Pers. PT. RajaGrafindo Persada.

Loges, William E., \& Ball-Rokeach, Sandra J. (1993). Dependency relations and newspaper readership. Journalism Quarterly, 70(3), 602-614. https://doi.org/10.1177/107769909307000311

Lowery, Shearon, \& De Fleur, Melvin. (1983). Milestones in mass communication research. Media effects. Nueva York.

Manab, H. Abdul. (2015). Penelitian Pendidikan Pendekatan Kualitatif. Kalimedia.

McIlwraith, Robert D. (1998). "I'm addicted to television": The personality, imagination, and TV watching patterns of self-identified TV addicts. Journal of Broadcasting \& Electronic Media, 42(3), 371-386. https://doi.org/10.1080/08838159809364456

McQuail, Denis. (1994). The rise of media of mass communication. Mass Communication Theory: An Introduction, 1-29. 
Rikky operiady.

Merton, Robert K. (1949). Patterns of Inluence: A Study of Interpersonal Influence and of Communications Behavior in a Local Community. In. Lazarsfeld, Paul F.Stanton, Frank, N.(ed.). Communications Research 1948-1949. New York: Harper \& Brothers.

Penyusun, Tim. (2013). Pedoman penulisan karya ilmiah. Universitas Maritim Raja Ali Haji.

Sari, Milya, \& Asmendri, Asmendri. (2020). Penelitian Kepustakaan (Library Research) dalam Penelitian Pendidikan IPA. Natural Science: Jurnal Penelitian Bidang IPA Dan Pendidikan IPA, 6(1), 41-53. 10.15548/nsc.v6i1.1555

Sugiyono, Metode. (2014). Penelitian Pendidikan Pendekatan Kuantitatif Kualitatif R\&D cet. Ke-19, Bandung: Alfabeta.

Syakirin, Muhammad Hamda, Aziz, Djisman, \& Surayya, Elly. (2020). Eksistensi Pondok Pesantren Wali Peetu dalam Menarik Minat Orang Tua Untuk Melanjutakan Pendidikan Agama Anak Di Desa Air Hitam Laut Kecamatan Sadu Kabupaten Tanjung Jabung Timur Provinsi Jambi. UIN Sulthan Thaha Saifuddin Jambi.

Thoyyib, Mochamad. (2018). Radikalisme Islam Indonesia. TA'LIM: Jurnal Studi Pendidikan Islam, 1(1), 90-105.

Usman, Sunyoto, Qodir, Zuly, \& Hasse, J. (2014). Radikalisme agama di Indonesia. Yogyakarta: Pustaka Pelajar.

Widyaningsih, Rindha, \& Fil, S. (2019). Deteksi Dini Radikalisme. Purwokerto: Unsoed Press. 